\title{
Winds of War: Epistemic and effective control in political discourse
}

Vientos de guerra: Control epistémico y efectivo en el discurso político

JUANA I. MARÍN-ARRESE

UNIVERSIDAD COMPLUTENSE DE MADRID

HTTPS://ORCID.ORG/0000-0002-1007-640X

ABSTRACT: This paper explores two key domains of speaker's stance in discourse: epistemic and effective stance (Marín-Arrese 2011, 2015, 2021). The framework draws on Langacker's $(2009,2013)$ distinction between the epistemic and the effective level in the grammar, and the systematic opposition thereof between striving for control of conceptions of reality and control of relations at the level of reality. Epistemic strategies pertain to the epistemic legitimisation of assertions, by providing epistemic support and epistemic justification for the proposition (Boye 2012). Effective control is aimed at the legitimisation of actions and plans of action. The joint deployment of epistemic and effective stance acts effects a strategy of combined control over hearers/readers' acceptance of conceptions of reality and of plans of action. This paper studies the strategic use of these resources in the discourse of war and presents a case study on their use by two politicians, President George W. Bush and Prime Minister Tony Blair, in political speeches and statements during the build-up to the second Iraq war. Results indicate significant qualitative and quantitative differences in the preferred stance strategies in the discourse of the two politicians.

Key words: epistemic stance, effective stance, legitimisation strategies, control, manipulation

RESUMEN: Este artículo explora dos dominios clave del posicionamiento del hablante en el discurso: posicionamiento epistémico y efectivo (Marín-Arrese 
2011, 2015, 2021). El marco analítico se inspira en la distinción de Langacker $(2009,2013)$ entre el nivel epistémico y el efectivo en la gramática, y en la oposición que se deriva entre pretender el control de las concepciones de la realidad y el control de las relaciones existentes a nivel de la realidad. Las estrategias epistémicas conciernen la legitimación epistémica de las aserciones, al aportar soporte epistémico y justificación epistémica para la proposición (Boye 2012). El control efectivo tiene por objeto la legitimación de acciones y planes de acción. El despliegue estratégico conjunto de actos de posicionamiento epistémico y efectivo realiza una estrategia combinada de control sobre la aceptación por parte de oyente/lector de concepciones de la realidad y de planes de acción. Este artículo estudia el uso estratégico de estos recursos en el discurso de la guerra, y presenta un estudio de caso sobre su uso por dos politicos, el Presidente George W. Bush y el Primer Ministro Tony Blair, en discursos politicos y declaraciones durante los preparativos para la segunda guerra de Irak. Los resultados indican diferencias significativas cualitativas y cuantitativas en las estrategías de posicionamiento preferidas por los dos politicos.

Palabras clave: posicionamiento epistémico, posicionamiento efectivo, estrategias de legitimación, control, manipulación.

\section{INTRODUCTION}

This paper explores epistemic and effective legitimisation strategies in the discourse of war. The framework is based on a model for the analysis of stancetaking which posits two macro categories of stance, the epistemic and the effective (Marín Arrese 2011, 2015, 2021). In characterising these two macro-categories, the model draws on Langacker's $(2009 ; 2013)$ distinction between the epistemic and the effective level, and the systematic opposition thereof between striving for control of conceptions of reality and control of relations at the level of reality. Epistemic stance pertains to speaker/writer's striving for control of conceptions of reality, which involves their estimation of the veracity of the event designated and the likelihood of its realization, and/or their specification of the sources of information whereby they feel entitled to make a factual claim. The category of effective stance pertains to the positioning of the speaker/writer with respect to the realization of events, to the ways in which the speaker/writer carries out a stance act aimed at determining or influencing the course of reality itself.

Epistemic stance strategies may serve ideological purposes in the striving for control of hearers' acceptance of information, by overcoming the epistemic safeguards of their audience and offering 'guarantees' for the truth of their assertions (Chilton 2004, 2011; Hart 2011). Speakers have a vested interest in justifying their assertions, since they may be held politically accountable for the veracity of their claims and for their decisions and actions based on those claims. Effective stance strategies are directly aimed at the legitimisation of actions, and the coercion of hearers/readers' acceptance of those actions and plans of action, by discursively constructing them as necessary, desirable, righteous, or feasible, and constructing the controllers as fully committed to those actions and plans. It will be argued that the joint deployment of epistemic and effective stance acts effects a strategy of combined control over hearers/readers' acceptance of particular conceptions 
of reality and of plans of actions and constitutes the basis for the legitimisation of specific actions and decisions.

This paper presents a case study on the use of epistemic and effective stance in discourses of war, and more specifically on the second Iraq War. Studies on the Gulf war and the second Iraq war have mainly focused on the use of metaphor or the use of topoi in the representation of social actors and events (Lakoff 1991; van Dijk 2005; Cap 2006; Mohammed Alrubaian 2019). The present case study examines the discourse of US President George W. Bush and UK Prime Minister Tony Blair, in the build-up to the Iraq War, from 11 September 2001 to the capture of Saddam Hussein in 2003. The aim is to characterize and to make visible their preferences in the deployment of epistemic and effective stance resources as legitimising strategies in the justification of the Iraq invasion, which may relate to differences in their perceived political involvement and interests, and thus in their rhetorical goals, or differences derived from the interactional identities of the two politicians.

The paper explores the following research questions:

(a) the degree to which there are similarities or significant differences in the use of expressions of epistemic and effective stance in the discourse of the two politicians.

(b) the degree to which there are similarities or significant differences in the pattern of distribution in the categories of epistemic and effective stance resources in the discourse of the two politicians, that is, whether they display a preference for particular categories of epistemic and effective resources.

It is hypothesized that there will be significant differences in the deployment of epistemic and effective stance strategies by Bush and Blair, and their preferred legitimising strategies, which may derive from: (a) interactional identities and intercultural discourse practices; (b) politicians' perceived political involvement and responsibility for the war.

In order to address these aims and hypotheses, the paper presents a quantitative study on the discourse of Bush and Blair during the build-up to the second Iraq war with the following research objectives:

(i) to identify, annotate and quantify epistemic stance markers in order to compare the categories and the variation in the deployment of these resources;

(ii) to identify, annotate and quantify effective stance markers in order to compare the categories and the variation in the deployment of these resources.

The paper is organized as follows. Section 2 discusses the domains of epistemic and effective stance. The case study is presented in Section 3. The results are discussed in section 4 . The final section is devoted to the conclusions.

\section{STANCE \& CONTROL IN DISCOURSE}

The multifaceted nature of stance has been linked to the expression of beliefs, attitudes or emotions, and positioning in the discourse, and has been addressed from diverse and often overlapping perspectives and frameworks, such as the work on stance (Biber and Finegan 1989; Biber 2015), affect and emotion (Ochs \& Schieffelin 1989, DuBois \& Kärkkäinen 2012), evaluation (Thompson and Hunston 2000; Thompson and Alba-Juez 2014), stancetaking and dialogicality (DuBois 2007; Englebretson 2007), and the sociolinguistics of stance (Jaffe 2009). Stancetaking strategies involve the use of a variety of lexico-grammatical elements which "overtly express an evaluative frame for some other proposition" (Biber at al. 1999: 967). 


\subsection{EPISTEMIC \& EFFECTIVE CONTROL}

Epistemic stance pertains to speaker's striving for control of conceptions of reality, for 'epistemic control' in the discourse (Langacker 2013). Speakers make strategic use of epistemic stance expressions in order to provide justificatory support for the proposition (cf. Boye 2012), with the aim of controlling hearers' acceptance of "the validity of a proposition" as "part of a conception of reality" (Langacker 2009: 303), and thus persuading them to accept the veracity of their claims.

Effective stance pertains to speaker's striving for control of relations at the level of reality (Langacker 2013), to their positioning with respect to the realization of actions and of plans of action. The relations profiled by effective control elements "represent actions or assessments aimed at determining what actually happens" (Langacker 2009: 303). As Langacker (2009: 167) notes, effective control elements are "force-dynamic at the social level, involving the exercise of authority because I am trying to make the hearer actually do something (not just think of it or acknowledge it)". Speakers make strategic use of effective stance expressions with the aim of urging for action and persuading or coercing hearers to accept those actions and decisions.

By exploiting 'epistemic legitimising strategies', speakers may indirectly manipulate hearers' acceptance of the veracity of their assertions, as a prior condition for the discursive legitimisation of actions, in the latter case through more direct coercive 'effective legitimising strategies' (Marín-Arrese 2011, 2021).

\subsection{PERSUASION, MANIPULATION \& COERCION}

Persuasion and persuasive intent have been addressed from various perspectives in the literature. From the field of evolutionary Psychology, Sperber et al. (2010: 359) have argued that "humans have a suite of cognitive mechanisms for epistemic vigilance, targeted at the risk of being misinformed by others", that is, the hearer's ability to detect deceptive language use ('cheater detector', Cosmides 1989), and their ability to assess the reliability of the source and the validity of the information ('source tagging', Cosmides and Tooby 2000). Chilton (2011: 772) notes that "human language could not have evolved without a cooperative assumption that predisposed humans to believe other communicators". But this natural tendency to accept as true and valid the communicated information is coupled with the need "to be epistemically vigilant and check for cheaters". Cheaters will then need to find ways "to circumvent the epistemic defences of their audiences", which would account for the development of the ability both "for persuasion" and "for detection of persuasive intent". Chilton (2011: 774), however, makes the caveat that "the tendency to accept is variable within and across situations, societies, polities and cultures", which raises the issue of why some claims go unchallenged or why some people fail to adopt a critical stance.

Critical discourse analysts focus on the use of deceptive tactics by the dominant groups (cf., Fairclough 1989; Van Dijk 2006). Pragma-cognitivists have studied the cognitive processes involved in manipulative language use (cf., Saussure 2005). Sorlin (2017: 133) argues for an approach which focuses on "the informational/beliefbased/cognitive impact of the phenomenon", that is, she defines manipulation in terms of "the (a) ulterior motives behind a communicative effort" and "the (b) course of actions the discourse generates". 
Sorlin (2017: 135) has argued that there is no clear dividing line between persuasion and manipulation, and that "what manipulators tamper with, cognitively speaking, is the Hearers' interpretative possibilities, limiting their 'freedom of interpretation' so to speak". The manipulative spectrum, according to Sorlin (2017), may be conceived as a continuum involving interpretative freedom, with 'persuasion' at one end and 'coercion' at the other, as in the following diagram:

Figure 1. The manipulative spectrum

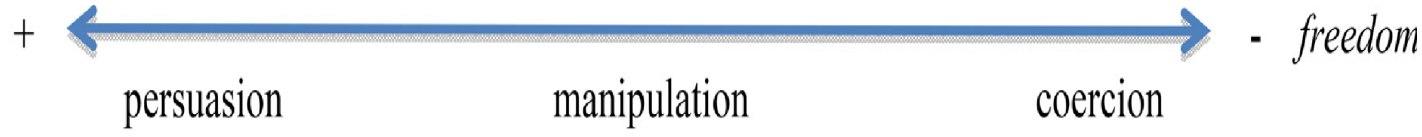

interpretative freedom

obligation to comply

(Sorlin, 2017: 136)

Persuasion presumably tends to be more "belief-based", involving the manipulator's intent to persuade Hearers "into adopting the Speaker's beliefs" (cf., 'epistemic control') through covert deception (Sorlin, 2017: 135). But in coercive manipulation, the manipulator would seek to impose some form of pressure on Hearers, "to coerce the victims into acting in a certain way (through linguistic/pragmatic -- not physical -- means)" (Sorlin, 2017. 135) (cf., 'effective control'). In sum, making others believe and do things, and thereby satisfying the interest of speakers/writers, is one of the main components of manipulative language use (van Dijk 2006).

An additional dimension of manipulation is the play on the Hearers' emotions and emotional needs (cf., Marín-Arrese 2021). This dimension is undoubtedly present in the discourse of the two politicians, though it is beyond the scope of this paper.

\section{THE CASE STUDY: EPISTEMIC \& EFFECTIVE STANCE}

\subsection{EPISTEMIC STANCE}

Categories of epistemic stance discursively construct (the reality status of) events as certain/probable or possible (epistemic modality), and the representation of events as verifiable (evidentiality), as fact (factives), or as beliefs (cognitive attitude) (MarínArrese 2015, 2021). The focus in this study is on those expressions which reflect a higher degree of commitment to the validity of the communicated information.

Epistemic stance (EP) resources include the following categories:

(a) Epistemic modals (EM): These express the speaker's assessment concerning the existence of the event designated, its actual or potential occurrence. Expressions of high or medium degree of epistemic support include epistemic necessity (must, certainly, of course) and probability modals (will, probably, likely).

(1) I recall a few weeks ago talking to an Iraqi exile and saying to her that I understood how grim it must $<$ EP, EM $>$ be under the lash of Saddam. (Blair-T13)

(2) Your response and probably $<\mathrm{EP}, \mathrm{EM}>$ that of most people would have been very similar to the response of some of you yesterday on Iraq. There would have been few 
takers for dealing with it and probably $<\mathrm{EP}, \mathrm{EM}>$ none for taking military action of any description. (Blair-T6)

(b) Indirect Inferential Evidentiality (IIE): Evidentials primarily indicate the source of information (Aikhenvald 2004), and the evidence on the basis of which the speaker feels entitled to make a factual claim (Anderson 1986). A broader conception of evidentiality also includes an estimation of source reliability, as Chafe (1986) posited in his seminal publication.

The focus here is on the subtype of Indirect Inferential Evidentiality (IIE). These expressions may indicate both perception-based and conception-based inferences (cf. Diewald and Smirnova 2010), as well as inferential meaning based on information acquired through oral and written texts (communication-based or report-based inferences) (cf. Marín-Arrese 2015a), as the following examples show. It is interesting to comment that Bush sometimes uses the perception predicate see, albeit with an indirect inferential value to refer to intentions of the agents described, but which strategically evokes direct perception of resulting actions. Expressions found with an indirect inferential value include the following: see, seem/s, clearly, obviously, plainly, it is clear/plain.

(3) We have seen $<E P$, IIE $>$ that those who hate America are willing to crash airplanes into buildings full of innocent people. (Bush-T8)

(4) What is perfectly clear $<E P$, IIE $>$ is that Saddam is playing the same old games in the same old way. Yes, there are concessions. But no fundamental change of heart or mind. (Blair-T13)

(c) Personal Cognitive Factives (CFV) and Impersonal Factives (IFV): Factive predicates are generally defined as presupposing the truth of the proposition designated by their complement clause (Kiparsky and Kiparsky 1970). These expressions indicate the speaker's assignment of knowledge status to a representation, that is, full support for the proposition, so that they reflect the speaker's high degree of epistemic support and speaker commitment. Personal cognitive factives (CFV) include expressions such as: $\mathrm{I} / \mathrm{we}$ know, I/we recall, I/we remember. Impersonal factives (IFV) are expressions such as: It is true, The fact is, The truth is.

(5) We know $<$ EP, CFV $>$ from prior weapons inspections that Saddam has failed to account for vast quantities of biological and chemical agents, including mustard agent, botulinum toxin and sarin, capable of killing millions of people. We know $<\mathrm{EP}, \mathrm{CFV}>$ the Iraqi regime finances and sponsors terror. And we know $<\mathrm{EP}, \mathrm{CFV}>$ the regime has plans to place innocent people around military installations to act as human shields. (Bush-T14)

In the discourse of both Blair and Bush we often find instances of the rhetorical strategy of repetition of the same stance expression at the beginning of successive clauses or sentences, in order to emphasise the veracity of their claims.

(6) Retreat might give us a moment of respite but years of repentance at our weakness would I believe $<\mathrm{EP}, \mathrm{CGA}>$ follow. It is true $<\mathrm{EP}$, IFV $>$ Saddam is not the only threat. But it is true $<\mathrm{EP}, \mathrm{IFV}>$ also - as we British know $<\mathrm{EP}, \mathrm{CFV}>-$ that the best way to deal with future threats peacefully, is to deal with present threats with resolve. (Blair-T14) 
(d) Cognitive Attitude (CGA): These are expressions which convey speakers' reflective attitudes or beliefs regarding events and representations. They may indicate different degrees of epistemic support for the proposition, from those close to a certainty level ( $\mathrm{I}^{\prime} \mathrm{m}$ convinced, I have no doubt, no doubt, undoubtedly) to those expressing partial support (I/we think, I/we believe).

(7) I am convinced $<\mathrm{EP}, \mathrm{CGA}>$ there is now a real wish across the world to push this process forward and I hope $<\mathrm{EF}$, INT $>$ we can $<\mathrm{EF}$, POT $>$ take further steps on this issue soon. I believe $<\mathrm{EP}, \mathrm{CGA}>$ it is of fundamental importance not just to peace in the Middle East but to the peace of the world. (Blair-T10)

(e) Marked Enunciational Positioning (MEP): These metadiscoursal comments perform the legitimising function of vouching for the communicated proposition. The speaker overtly marks the act of enunciation, explicitly signalling themselves as the origo of the claim, and personally and explicitly vouches for the communicated information. This strategic use of expressions constitutes an additional dimension of speaker's stance and commitment, where the speaker shifts from the basic, unmarked enunciational position to an overt emphatic function (cf. Brandt 2004). Examples of this use of speech-act predicates in performative utterances are the following: I say (to you), I have to say, I (should) emphasise, I repeat, I can confirm, I can tell, to put it plainly.

At the outset, I say $<$ EP, MEP $>$ : it is right $<E F, N R M>$ that the House debate this issue and pass judgment. That is the democracy that is our right, but that others struggle for in vain. Again, I say $<$ EP, MEP $>$ : I do not disrespect the views of those in opposition to mine. (Blair-T13)

Metadiscourse is defined by Ädel (2010: 75) as "reflexive linguistic expressions referring to the evolving discourse itself or its linguistic form, including references to the writerspeaker qua writer-speaker and the (imagined or actual) audience qua audience of the current discourse". In these cases of metadiscourse framing, the validity assigned by hearers to the communicated information would normally depend on the "evidential standing" of the speaker as source (White 2006: 64). In this case study, an obvious feature of authority and credibility which may be exploited by the speakers is the fact that the two politicians are supposedly 'experts' in matters of national security.

\subsection{EFFECTIVE STANCE}

Effective stance strategies discursively construct proposed actions and decisions as necessary (Deonticity: "We must act"), desirable (Normativity: "We abide by social norms and social morality"), and possible (Potentiality: "We can"), and construct the controllers as fully committed to those actions and decisions (Intentionality: "I/We have the will", "I/We am/are committed") and to their enforcement (Directivity: "I urge you to").

This paper focuses on those effective expressions which indicate a higher degree of speaker's striving for control, that is, a higher degree of involvement in achieving their aims and in their commitment to some course of action.

Effective stance (EF) categories and expressions are the following:

(a) Deonticity (DM): Within this category we include expressions of deontic modality and participant-external necessity (must, should, cannot) (cf. van der Auwera and 
Plungian 1998). Similar meanings are expressed by so-called semi-modals or quasimodals (have to, need to) (cf. Leech 2003). Examples found include: must, should, cannot, can't, has/have to, need/s to.

As a rhetorical device, in the discourse of Blair we often find reiteration of the same stance expression for emphasis and to stress the need for some course of action, as in the following example.

(9) Mr Speaker, in the face of this evidence, our immediate objectives are clear. We must $<\mathrm{EF}, \mathrm{DM}>$ bring Bin Laden and other Al Qaida leaders to justice and eliminate the terrorist threat they pose. And we must $<\mathrm{EF}, \mathrm{DM}>$ ensure that Afghanistan ceases to harbour and sustain international terrorism. If the Taleban regime will not comply with that objective, we must $<\mathrm{EF}, \mathrm{DM}>$ bring about change in that regime to ensure that Afghanistan's links to international terrorism are broken. (Blair-T3)

(b) Directivity (DIR): This category includes the use of the imperative with a conventional directive force (do not), or with a hortative value (Let us/Let's), and the performative uses of verbs of communication with a directive illocutionary force (I ask you, I urge you to), as well as indirect directives (I/we want you to).

(10) There is no complexity about Resolution 1441 . I ask $<$ EF, DIR $>$ all reasonable people to judge for themselves: After 12 years is it not reasonable that the UN inspectors have unrestricted access to Iraqi scientists $-[\ldots]$ ? (Blair-T11)

(c) Normativity (NRM): This category reflects the claims to social desirability or requirement of proposed plans of action. Expressions include personal and impersonal predicates designating judgements of desirability or advisability of the event's realization (It is essential, It is crucial, It is time), or its social justification and righteousness (it is right, it is fair, it will not do).

(11) This is not the time $<\mathrm{EF}, \mathrm{NRM}>$ to falter. This is the time $<\mathrm{EF}, \mathrm{NRM}>$ for this House, not just this Government-or, indeed this Prime Minister-but for this House to give a lead, to show that we will $<\mathrm{EF}$, INT $>$ stand up for what we know $<$ EP, CFV $>$ to be right, to show that we will $<\mathrm{EF}$, INT $>$ confront the tyrannies and dictatorships and terrorists who put our way of life at risk, to show, at the moment of decision, that we have the courage to do the right thing. (Blair-T13)

(d) Intentionality (INT): This category comprises those expressions which express intention, inclination, volition, or commitment. Grouped here are modals of volition, with a commissive illocutionary force (I/we will/'ll/won't), personal predicates designating speaker's inclination (I would like, we hope), and 'emerging' modals of volition or intention, or commitment (I/we want, I am/we are going to) (Krug 2000). The expression of resolve or strong intention is found in some 'effective matrix predicates' (we are determined, we are resolved) (cf. Langacker 2009).

(12) We will $<$ EF, INT $>$ starve terrorists of funding, turn them one against another, drive them from place to place, until there is no refuge or no rest. And we will $<$ EF, INT $>$ pursue nations that provide aid or safe haven to terrorism. Every nation, in every region, now has a decision to make. Either you are with us, or you are with the terrorists. (Bush-T2) 
Rhetorical effects involving repetition are often found in the discourse of Bush. It is quite common to find a cumulative effect through the use of various expressions of the same category involving the effect of an increase in force of commitment.

(13) We will $<$ EF, INT $>$ not wait to see what terrorists or terror states could do with weapons of mass destruction. We are determined $<\mathrm{EF}$, INT $>$ to confront threats wherever they arise. And, as a last resort, we must $<\mathrm{EF}, \mathrm{DM}>$ be willing to use military force. (Bush-T13)

This example provides an interesting progression from intention to determination, with a final show of deontic force involving all the American citizens. Also interesting is the strategic play on intersubjectivity (evoking inclusive collective commitment).

(e) Potentiality (POT): This category includes expressions of participant-internal possibility, which refers to "a participant's ability (capacity)" to carry out the event designated, and of participant-external possibility, which invokes the circumstances external to the participant which make the event possible (van der Auwera and Plungian 1998: 80). The persuasive potential of these expressions lies in the attempt by speakers to raise hearers' 'awareness' of the possibility of the realization of events and actions. Expressions in this category include root modals of possibility: We can, you can.

(14) All the world can $<$ EF, POT $>$ rise to this moment. The community of free nations can $<$ EF, POT $>$ show that it is strong and confident and determined to keep the peace. The United Nations can $<E F$, POT $>$ renew its purpose and be a source of stability and security in the world. The Security Council can $<E F$, POT $>$ affirm that it is able and prepared to meet future challenges and other dangers. And we can $<$ EF, POT $>$ give the Iraqi people their chance to live in freedom and choose their own government. (Bush-WT11)

\section{THE CASE STUDY: METHODOLOGY}

The corpus study explores the use of epistemic and effective stance expressions as strategies of legitimisation of the invasion of Iraq in 2003, in a series of public speeches, statements and press conferences by George W. Bush, President of the US (2001-2009), and by Tony Blair, British Prime Minister (1997-2007).

\subsection{THE CONTEXT}

The Iraq War began on 20 March 2003, when an invasion force led by the United States invaded Iraq. Following terrorist attacks in the US, on 11 September 2001, George W. Bush initiated the 'War on Terror', whose first effects were seen in the 2001 invasion of Afghanistan. Tony Blair strongly supported the foreign policy of George W. Bush, participating in the 2001 invasion of Afghanistan and 2003 invasion of Iraq. The capture of Saddam Hussein took place on $13^{\text {th }}$ December 2003. The US completed its withdrawal of military personnel in December 2011.

Last minute preparations for the Iraq war presumably took place at the summit meeting at The Azores, on 16 March 2003, between US president George W. Bush, British Prime Minister Tony Blair, and Spanish President of Government José María Aznar, hosted by Portugal's Prime Minister Jose Durao Barroso. Statements of the 
Atlantic Summit included the following: 'Commitment to Transatlantic Solidarity' and 'A Vision for Iraq and the Iraqi People'.

The invasion of Iraq was particularly controversial in the UK, as it attracted widespread public opposition, including that of a substantial number of Blair's MPs, as well as the Cabinet resignations of Guy Cook and Clare Short. At the time of the invasion and subsequently in the Iraq War Inquiry, Blair faced severe criticism over the policy itself and the circumstances in which it was decided upon.

\subsection{THE TEXTS}

From 11 September 2001 to the 2003 invasion of Iraq, both Bush and Blair delivered a substantial number of public and institutional addresses centred on the issue of the 'War on Terror'. This paper examines a variety of texts within that time frame and up the capture of Saddam Hussein.

(i) BUSH: Address to the Nation, address to Congress, radio addresses, and key public speeches (22 texts, 27,917 words).

(ii) BLAIR: Parliamentary statements, and key public statements and speeches (16 texts; 27,988 words).

The variety of text types inevitably means that there will be certain genre-related variation in the use of epistemic and effective stance resources, which is beyond the scope of this study. Also, since most of the texts by Blair are parliamentary statements, there might be both cultural and normative differences in the way the speaker displays rhetorical strategies of persuasion and legitimisation, in comparison to the various public addresses by Bush.

\subsection{RESEARCH QUESTIONS, HypotheSES AND RESEARCH OBJeCTIVES}

The corpus study looks at the presence and patterning of stance markers in each sub-corpus, as expressions of epistemic or effective stance. The case study explores the following issues:

(i) Whether there is variation in the use of epistemic and effective stance resources in the discourse of the two politicians;

(ii) Whether there is variation in the pattern and distribution of the categories of effective and epistemic stance in the discourse of the two politicians.

The assumption is that the particular discourse domain (political discourse), and the specific topic (war) and rhetorical goals (persuasion/coercion, justification of the legitimacy of war) will in great part determine the type and frequency of epistemic and effective stance expressions. It is hypothesized that there will be significant differences in the deployment of epistemic and effective stance strategies by Bush and Blair, and their preferred categories of epistemic and effective legitimising strategies. Variation in the use of stance resources between speakers may derive from: (a) differences in interactional identities and intercultural discourse practices in argumentative and persuasive styles, (b) differences in the politicians' perceived political involvement and degree of responsibility and accountability for the war.

The paper posits the following null hypotheses:

(i) $\mathrm{H}_{0} 1$ (Dependent variable: DV/Independent variable: IV): There is no difference between the frequency of epistemic stance expressions and effective stance expressions (DV) in the discourse of Bush and Blair (IV).

The null hypothesis is expressed as $\mathrm{H}_{01}: \pi 1=\pi 2$ 
(ii) $\mathrm{H}_{0} 2$ (Dependent variable: DV/Independent variable: IV): There is no difference between the pattern of distribution of categories of epistemic stance (DV) in the discourse of Bush and Blair (IV).

The null hypothesis is expressed as $\mathrm{H}_{02}: \pi 1=\pi 2$

(iii) $\mathrm{H}_{0} 3$ (Dependent variable: DV/Independent variable: IV): There is no difference between the pattern of distribution of categories of effective stance (DV) in the discourse of Bush and Blair (IV).

The null hypothesis is expressed as $\mathrm{H}_{03}: \pi 1=\pi 2$

The following research objectives are set in relation to the above hypotheses:

(a) Identification of stance expressions in the texts: epistemic and effective.

(b) Analysis of the texts, identifying the categories of epistemic and effective stance, and manual annotation of data.

(c) Quantification (using Monoconc), and comparison of the quantitative results in the discourse of the two politicians: Bush vs. Blair.

(d) Statistical analysis of the quantitative results: SIGIL online utilities for statistical inference (Corpus Frequency Test Wizard) <http://www.stefan-evert.de/SIGIL/>, and UCREL's Log likelihood wizard for frequency comparison $<$ http://ucrel.lancs.ac.uk/llwizard.html $>$.

\subsection{RESEARCH PROCEDURE}

The texts were annotated manually, and searches were made using Monoconc to ensure that all instances of stance expressions were identified. Frequency comparison of stance expressions was carried out using UCREL's Log-likelihood (LL) test, which indicates whether there is relative overuse or underuse of the observed frequency $\left(\mathrm{O}_{1}\right)$ in Corpus 1 in comparison to the observed frequency $\left(\mathrm{O}_{2}\right)$ in Corpus 2: overuse in corpus 1 relative to corpus 2 is indicated by ' + ', and underuse is coded with a '-' sign (differences in scores are significant at $>3.84$ score). The log-likelihood test was applied to each category of stance in the two corpora.

Relative frequencies and possible associations between the variables was tested using the SIGIL online utilities for statistical inference (Corpus Frequency Test Wizard), which provide frequency comparisons between corpora, and give relative frequencies of tokens for each category (per thousand words). A Chi-square test was run to establish whether there was association between the use of stance resources by the two politicians (Bush vs. Blair) and the frequency of tokens in each of the categories of epistemicity and effectivity. The value of significance was established at $p<0.05$. Results for FCT values of $\mathrm{X}^{2}$ are marked as: $* * *$ significant at $\mathrm{p}<.001, * *$ significant at $\mathrm{p}<.01$, *significant at $\mathrm{p}$ $<.05$.

The criteria for the inclusion/exclusion of expressions found in the texts were the following:

(i) The focus is on those expressions which reflect a higher degree of epistemic support and epistemic justification for the assertion or claim. Excluded: modals of "neutral support", possibility and uncertainty (may, perhaps).

(ii) Expressions having propositional scope where the profiled occurrence is immediate to the ground ( $\mathrm{know}$ ); all the expressions which are cases of non-immediacy (I was aware) have been excluded (cf. Langacker 2009).

(iii) Included only high and medium commitment expressions. Modal will with a predictive or a predictability meaning was included. Excluded: modal will designating future and planned events. Excluded: modal will under the scope of a cognitive attitude or cognitive factive predicate. 
(iv) Excluded: modals will and would in an irrealis context, such as if-clauses and other expressions within if-clauses (protasis), and non-assertive modalities or contexts (questions).

(v) Excluded: modal expressions under the scope of matrix predicates not indexing the speaker as conceptualizer.

(vi) Excluded: discourse-pragmatic markers functioning as management markers or style disjuncts (you know, you see, I mean), and metadiscourse expressions involving references to the audience.

\section{RESULTS AND DISCUSSION}

The results for effective and epistemic stance resources, Table 1, show that the preferred type of legitimisation in the discourse of the two politicians is the use of effective strategies.

Table 1. Effective vs. Epistemic Stance (raw numbers, percentage and relative frequency per 1,000 words)

\begin{tabular}{|c|c|c|c|c|c|c|}
\hline \multirow{3}{*}{ STANCE } & \multicolumn{3}{|c|}{ BUSH } & \multicolumn{3}{|c|}{ BLAIR } \\
\hline & \multicolumn{3}{|c|}{27,917 words } & \multicolumn{3}{|c|}{27,988 words } \\
\hline & $\mathbf{N}$ & $\%$ & $\mathbf{R}$ & $\mathbf{N}$ & $\%$ & $\mathbf{R}$ \\
\hline Epistemic (EP) & 139 & 23.4 & 4.98 & 274 & 42.2 & 9.79 \\
\hline Effective (EF) & 451 & 76.6 & 16.15 & 376 & 57.8 & 13.43 \\
\hline TOTAL & 590 & 100 & 21.13 & 650 & 100 & 23.22 \\
\hline
\end{tabular}

This preference is particularly marked in the case of Bush, totalling $76.6 \%$ of the stance resources used. Blair also shows a clear tendency to use effective expressions, $57.8 \%$, but balanced by a considerable number of epistemic stance expressions, $42.2 \%$. There are also differences between the two politicians in the overall figures for the ratios: Blair makes a significantly higher use of stance expressions in general $(\mathrm{R}=23.22)$, which is patent in the higher use of epistemic expressions $(\mathrm{R}=9.79)$, which practically doubles the ratio of use by Bush $(\mathrm{R}=4.98)$.

With respect to Hypothesis 1, a chi-square test of independence was performed to examine the relation of the distribution of the categories of effective and epistemic stance (dependent variable) and the speaker variable (independent variable). Results (chi-square statistic with Yates correction $=47.3061, p$-value is $<.00001$; significant at $p<.05$ ) indicate that the relation between these variables is significant so that the null hypothesis, $\mathrm{H}_{01}$, may be discarded.

Blair seems to effectively combine epistemic and effective resources in striving for control of both conceptions of reality and control of relations at the level of reality in urging for action. In contrast, Bush appears to be focused on the more direct strategy of control of relations at the level of reality.

\subsection{EPISTEMiC STANCE: RESUlTS}

Table 2 shows the results for the categories of Epistemic Stance for both politicians. 
Table 2. Categories of Epistemic Stance (raw numbers, percentage and relative frequency per 1,000 words)

\begin{tabular}{|c|c|c|c|c|c|c|}
\hline \multirow{3}{*}{$\begin{array}{l}\text { EPISTEMIC } \\
\text { STANCE }\end{array}$} & \multirow{2}{*}{\multicolumn{2}{|c|}{$\frac{\text { BUSH }}{27,917 \text { words }}$}} & \multirow{2}{*}{\multicolumn{2}{|c|}{$\frac{\text { BLAIR }}{27,988 \text { words }}$}} & \multirow{2}{*}{\multicolumn{2}{|c|}{ BUSH vs. BLAIR }} \\
\hline & & & & & & \\
\hline & $\mathbf{N}$ & $\mathbf{R}$ & $\mathbf{N}$ & $\mathbf{R}$ & $\mathrm{X}^{2}$ & LL \\
\hline EM & 70 & 2.791 & 90 & 3.215 & 2.21459 & -2.46 \\
\hline IIE & 12 & 0.429 & 26 & 0.928 & 4.41742 & -5.25 \\
\hline CGA & 18 & 0.645 & 51 & 1.822 & 14.77767 *** & -16.36 \\
\hline CFV & 29 & 1.038 & 40 & 1.429 & 1.42575 & -1.73 \\
\hline IFV & 2 & 0.071 & 19 & 0.678 & 12.15445 *** & -15.86 \\
\hline MEP & 8 & 0.286 & 48 & 1.715 & $27.08892 * * *$ & -31.60 \\
\hline Total EP & 139 & 4.979 & 274 & 9.789 & $43.45842 * * *$ & -49.14 \\
\hline
\end{tabular}

With respect to Hypothesis 2, there is a significant relationship between the pattern of distribution of the subcategories (dependent variable) and the two speakers (chi-square statistic $=18.5799$, $\mathrm{p}$-value $=.00095$; significant at $\mathrm{p}<.05$ ). Results indicate that the null hypothesis may be discarded and we may adopt the alternative hypothesis, $\mathrm{H}_{\mathrm{a} 2}$, which claims that variation is due to association between the variables.

The frequency comparison test (FCT) for each of the subcategories shows that differences between both politicians are significant for the categories of cognitive attitude (CGA), impersonal factives (IFV) and marked enunciational positioning (MEP). Overuse of expressions in these categories is very significant in the discourse of Tony Blair: the subjective expression of beliefs (CGA), the claims to what is true or fair (IFV), and the overt marking of the act of enunciation (MEP) appear to be distinct features of his rhetoric of legitimisation (cf., results of his oral evidence in the Iraq War Inquiry hearings, November 2009 - February 2011, Marín-Arrese 2015b). His discourse stance seems to reflect Blair's concern with his image and personal credibility, and with the acceptance of his claims by the audience. The Log-likelihood (LL) score shows significant overuse in these categories and in the total of expressions of epistemicity $(-49.14)$ in the discourse of Blair.

In striving for epistemic control, both speakers show a preference for expressions of epistemic modality, which involve a lower degree of commitment to the validity of the communicated information. As Bybee et al. (1994: 179) observe concerning epistemicity and truth, «markers of epistemic modality indicate something about less than a total commitment by the speaker to the truth of the proposition». It would seem that both speakers are reluctant to fully commit to the conceptions of reality they propound.

\subsection{EFFECTIVE STANCE: RESUlTS}

Table 3 shows the results for the categories of Effective stance. With respect to Hypothesis 3, the pattern of distribution of the categories of effective stance is also significant (chi-square statistic $=36.8401$, $p$-value $=<0.00001$; significant at $p<.05$ ), so that we may discard the null hypothesis and adopt the alternative hypothesis, $\mathrm{H}_{\mathrm{a} 3}$, that variation is due to association between the dependent variable of the categories of effective stance and the independent variable of the speakers. 
Table 3. Categories of Effective Stance (raw numbers, percentage and relative frequency per 1,000 words)

\begin{tabular}{|c|c|c|c|c|c|c|}
\hline \multirow{3}{*}{$\begin{array}{l}\text { EFFECTIVE } \\
\text { STANCE }\end{array}$} & \multirow{2}{*}{\multicolumn{2}{|c|}{$\frac{\text { BUSH }}{27,917 \text { words }}$}} & \multirow{2}{*}{\multicolumn{2}{|c|}{$\frac{\text { BLAIR }}{27,988 \text { words }}$}} & \multirow{2}{*}{\multicolumn{2}{|c|}{ BUSH vs. BLAIR }} \\
\hline & & & & & & \\
\hline & $\mathbf{N}$ & $\mathbf{R}$ & $\mathbf{N}$ & $\mathbf{R}$ & $\mathrm{X}^{2}$ & $\mathbf{L L}$ \\
\hline DM & 122 & 4.370 & 135 & 4.823 & 0.53270 & -0.63 \\
\hline DIR & 38 & 1.361 & 50 & 1.786 & 1.34933 & -1.61 \\
\hline NRM & 15 & 0.537 & 28 & 1.000 & 3.32099 & -3.96 \\
\hline INT & 212 & 7.594 & 104 & 3.716 & $36.71087 * * *$ & +37.94 \\
\hline POT & 64 & 2.293 & 59 & 2.108 & 0.14075 & +0.22 \\
\hline Total EF & 451 & 16.155 & 376 & 13.434 & $6.91310 * *$ & +7.00 \\
\hline
\end{tabular}

Within effective stance, the frequency comparison test (FCT) for each of the subcategories shows that Bush significantly favours the expressions of Intentionality (INT), and that the total figures for effectivity are also significantly higher. The differences in the use of expressions in the other categories are not significant. Blair shows a marked preference for expressions of Deontic modality (DM), and to a lesser extent for Intentionality (INT). The log-likelihood (LL) scores indicate a very significant overuse (+37.94) by Bush of expressions of Intentionality (INT) with respect to Blair.

These differences might have a contextual basis, in that most of the speeches and statements by Bush are addressed to the American people, to whom he makes pledges regarding their victory over Sadam, guaranteeing the future safety of the USA. Blair, on the other hand, is mostly addressing the House in his statements, so his main concern is that of urging the MPs to back his policy of support for the invasion of Iraq. In the discourse of Blair, the higher ratio and overuse of expressions of Deontic modality (DM) and Directivity (DIR), in urging the House for action is also congruent with the contextual basis, as is the overuse of Normativity (NRM) with Blair's predilection for 'ethical discourse' (cf., Charteris-Black 2005, for Blair's use of metaphor in political discourse; Charteris-Black 2011, for use of metaphor by Bush).

\section{CONCLUSION}

This paper has explored the strategic use of epistemic and effective stance resources in the discourse of war, and more specifically, in a series of key speeches, statements and addresses by Bush and by Blair, on the 'War on Terror' and the involvement of Iraq, from 11 September 2001 to the capture of Saddam Hussein in 2003. It has been argued that the joint deployment of epistemic and effective stance resources conforms a strategy of striving for combined control in the discourse over hearers/readers' acceptance of conceptions of reality and belief states about the 'War on Terror', which constitute the basis for control of relations at the level of reality, for the legitimisation of particular actions and decisions taken thereof. Epistemic stance resources realize the indirect legitimisation strategy of providing epistemic justificatory support, knowledge and information, for the speaker's proposed conception of reality, while effective stance resources provide a more direct strategy of urging for action by claiming the necessity, desirability, righteousness or feasibility of the proposed plans of action, or the speaker's commitment towards those proposed actions.

Regarding the categories of epistemic stance, both speakers show a preference for expressions of epistemic modality (EM), which reflect a lower commitment to the validity 
of the communicated information. Overall, results for epistemic stance are low for Bush in comparison with Blair, who shows significant figures for expressions of cognitive attitude (CGA) and impersonal expressions of factivity (IFV). Also notable is Blair's use metadiscoursal comments involving marked enunciational positioning (MEP), which seems to play a distinct role in his goal of epistemic control in the discourse. One may surmise that in having to answer to Parliament, Blair is under greater pressure regarding responsibility for his assertions and communicated information, as well as accountability for actions and decisions thereby legitimised (cf., the Iraq War Inquiry, 2009-2011).

Results for effective stance expressions point to a significant preference for effectivity over epistemicity in the discourse of Bush, whose preferred strategy is the use of expressions of intentionality (INT). Since Bush is addressing the American people in most of his speeches and statements, he is primarily concerned with expressing his commitment to the victory over Sadam, which involves both retribution for the 9/11 attacks and the guarantee of future safety in the USA. On the other hand, results for Blair show a marked preference for Deontic modality (DM) and Directivity (DIR), which reflect his main concern in urging Parliament to support the invasion of Iraq, and side with the USA in international relations.

Further research is necessary regarding the extent to which these stancetaking patterns may reflect speakers' interactional identities, in speeches on non-war issues, and the possible variation in different genres of political discourse. Some studies seem to point to a tendency towards mitigation and decreased commitment in the discourse of Blair, a result of his preference for expressions of epistemic modality (EM), as well as the use of agnostic stance (Brandt 2004) markers reflecting reluctance to commit to his assertions in his role as witness in the IWI (Marín-Arrese, 2015). A study on epistemic and effective stance in the farewell address by Bush shows a preferred tendency for the use of effective stance, as well as the use of expressions of epistemic modality (EM) as his main choice in the domain of epistemicity (Hidalgo-Downing, 2021).

\section{ACKNOWLEDGEMENTS}

This paper has received support from the project 'Stance and Subjectivity in Discourse: Towards an integrated framework for the analysis of Epistemicity, Effectivity, Evaluation and Inter/Subjectivity from a Critical Discourse Perspective' (STANCEDISC), Ref. PGC2018-095798-B-I00, funded by the Ministerio de Ciencia, Innovación $y$ Universidades.

\section{REFERENCES}

Ädel, Annelie. 2010. "Just to give you kind of a map of where we are going: A taxonomy of metadiscourse in spoken and written academic English". Nordic Journal of English Studies, 9 (2): 69-97.

Aikhenvald, Alexandra. 2004. Evidentiality. Oxford: Oxford University Press.

Anderson, Lloyd. 1986. "Evidentials, paths of change, and mental maps: Typologically regular asymmetries". In Evidentiality: The Linguistic Coding of Epistemology, eds. W. Chafe \& J. Nichols (pp. 273-312). Norwood, NJ: Ablex.

Biber, Douglas. 2015. "Stance and grammatical complexity: an unlikely partnership discovered through corpus analysis". Corpus Linguistics Research, 1: 1-19.

Biber, Douglas and Edward Finegan. 1989. "Styles of stance in English: Lexical and grammatical marking of evidentiality and affect". Text, 1: 93-124. 
Biber, Douglas, Stig Johansson, Geoffrey Leech, Susan Conrad, and Edward Finnegan. 1999. Longman Grammar of Spoken and Written English. London: Longman.

Boye, Kasper. 2012. Epistemic meaning: A crosslinguistic and functional-cognitive study. Berlin: Mouton de Gruyter.

Brandt, Per Aage. 2004. "Evidentiality and Enunciation. A Cognitive and Semiotic Approach". In Perspectives on Evidentiality and Modality, ed. Juana I. MarínArrese (pp. 3-10). Madrid: Editorial Complutense.

Bybee, Joan, Revere Perkins and William Pagliuca. 1994. The Evolution of Grammar: Tense, Aspect, and Modality in the languages of the world. Chicago: University of Chicago Press.

Cap, Piotr. 2006. Legitimisation in political discourse: a cross-disciplinary perspective on the modern US war rhetoric. Newcastle, U.K.: Cambridge Scholars Press.

Chafe, Wallace. 1986. "Evidentiality in English conversation and academic writing". In Evidentiality: The Linguistic Coding of Epistemology, eds. W. Chafe \& J. Nichols (pp. 261-272). New York: Ablex.

Charteris-Black, Jonathan. 2005. Politicians and Rhetoric. The Persuasive Power of Metaphor. Basingstoke/New York: Palgrave MacMillan.

Charteris-Black, Jonathan. 2011. Politicians and Rhetoric. The Persuasive Power of Metaphor, $2^{\text {nd }}$ ed. Basingstoke/New York: Palgrave MacMillan.

Chilton, Paul. 2004. Analysing Political Discourse. London: Routledge.

Chilton, Paul. 2011. "Still something missing in CDA". Discourse Studies, 13 (6): 769781.

Cosmides, Leda (1989). "The logic of social exchange: Has natural selection shaped how humans reason? Studies with the Wason selection task". Cognition, 31: 187-276.

Cosmides, Leda and John Tooby (2000). "Consider the source: The evolution of adaptations for decoupling and metarepresentations". In Metarepresentation: A multidisciplinary perspective, ed. D. Sperber (pp. 53-116). Oxford: Oxford University Press.

Diewald, Gabriele and Elena Smirnova. 2010. Evidentiality in German. Linguistic Realization and Regularities in Grammaticalization. Berlin: Mouton de Gruyter.

DuBois, John W. 2007. "The stance triangle". In Stancetaking in Discourse, ed. R. Englebretson (pp. 139-182). Amsterdam: John Benjamins.

DuBois, John W. and Elise Kärkkäinen. 2012. "Taking a stance on emotion: affect, sequence, and intersubjectivity in dialogic interaction". Text \& Talk, 32 (4): 433451.

Englebretson, Robert. 2007. "Introduction". In Stancetaking in Discourse, ed. R. Englebretson (pp. 1-26). Amsterdam: John Benjamins.

Fairclough, Norman, 1989. Language and Power. Longman, London.

Hart, Christopher. 2011. "Legitimising Assertions and the Logico-Rhetorical Module: Evidence and Epistemic Vigilance in Media Discourse on Immigration". Discourse Studies, 13 (6): 751-769.

Hidalgo-Downing, Laura. 2021. "Stance and identity in Barak Obama and George W. Bush's farewell addresses to the nation: Effectivity, epistemicity and (contrastive) negation". In Epistemicity and Stance in English and Other European languages: Discourse-Pragmatic Perspectives, eds. Juana I. Marín-Arrese, Anna Ruskan. Special issue of Journal of Pragmatics. Special issue. Journal of Pragmatics, 185: 93-107.

Hunston, Susan and Geoff Thompson (eds.) 2000. Evaluation in Text: Authorial Stance and the Construction of Discourse. Oxford: Oxford University Press. 
Jaffe, Alexandra (ed.) 2009. Stance: Sociolinguistic Perspectives. Oxford, Oxford University Press.

Johnstone, Barbara. 2007. "Linking identity and dialect through stancetaking". In Stancetaking in Discourse, ed. R. Englebretson (pp. 49-68). Amsterdam: John Benjamins.

Kiparsky, Paul and Carol Kiparsky. 1970. "Fact". In Progress in Linguistics, eds. Manfred Bierwisch and Karl E. Heidolph (pp. 143-73). The Hague: Mouton.

Krug, Manfred G. 2000. Emerging English modals: a corpus-based study of grammaticalization. Berlin and New York: Mouton de Gruyter.

Lakoff, George. 1991. "Metaphor and War: The Metaphor System Used to Justify War in the Gulf". Peace Research, 23: 25-32.

Langacker, Ronald W. 2008. Cognitive Grammar. A Basic Introduction. Oxford: Oxford University Press.

Langacker, Ronald W. 2009. Investigations in Cognitive Grammar. Berlin: Mouton de Gruyter.

Langacker, Ronald W. 2013. "Modals: Striving for control”. In English Modality: Core, Periphery and Evidentiality, eds. J.I. Marín-Arrese, M. Carretero, J. Arús and J. van der Auwera (pp. 3-55). Berlin, Mouton de Gruyter.

Leech, Geoffrey N. 2003. "Modality on the move: The English modal auxiliaries 19611992". In Modality in Contemporary English, eds. Roberta Facchinetti, Manfred Krug and Frank R. Palmer (pp. 223-240). Berlin: Mouton de Gruyter.

Lucy, John. 1993. "Reflexive language and the human disciplines". In Reflexive language: Reported speech and metapragmatics, ed. J. Lucy (pp. 9-32). Cambridge: Cambridge University Press.

Marín-Arrese, Juana I. 2011. "Effective vs. Epistemic Stance and Subjectivity in Political Discourse: Legitimising Strategies and Mystification of Responsibility". In Critical Discourse Studies in Context and Cognition, ed. Christopher Hart (pp. 193-223). Amsterdam: John Benjamins.

Marín Arrese, Juana I. 2015a. "Epistemicity and Stance: A cross-linguistic study of epistemic stance strategies in journalistic discourse in English and Spanish. A Cross-linguistic Perspective". Discourse Studies, 17 (2): 210-225.

Marín-Arrese, Juana I. 2015b. "Epistemic Legitimisation and Inter/Subjectivity in the Discourse of Parliamentary and Public Inquiries: A contrastive case study". Critical Discourse Studies, 12 (3): 261-278.

Marín-Arrese, Juana I. 2021. "Stance, Emotion and Persuasion: Terrorism and the Press". Journal of Pragmatics, 177: 135-148.

Mohammed Alrubaian, Haifa. 2019. Thirteen years apart...the Iraq wars a critical cognitive analysis of the use of metaphors in the representation of the two wars. $\mathrm{PhD}$ thesis. Madrid: Universidad Complutense de Madrid.

Ochs, Elinor and Schieffelin, Bambi. 1989. "Language has a heart". In The Pragmatics of Affect, ed. Ochs, E., special issue of Text, 9: 7-25.

Oswald, Steve. 2011. "From interpretation to consent: Arguments, beliefs and meaning". Discourse Studies, 13 (6): 806-814.

Saussure, Louis (de). 2005. "Manipulation and cognitive pragmatics. Preliminary hypotheses". In Manipulation and Ideologies in the Twentieth Century, eds. L. Saussure, L. and P. Schulz (pp. 113-145). Amsterdam: John Benjamins.

Sorlin, Sandrine. 2017. "The pragmatics of manipulation: Exploiting im/politeness theories". Journal of Pragmatics, 121: 132-146. 
Sperber, Dan, Fabrice Clement, Christophe Heintz, Olivier Mascaro, Hugo Mercier, Gloria Origgi and Deirdre Wilson. 2010. "Epistemic vigilance". Mind and Language, 25 (4): 359-393.

Thompson, Geoff and Alba-Juez, Laura (eds.) 2014. Evaluation in Context. Amsterdam: John Benjamins.

van der Auwera, Johan and Vladimir Plungian. 1998. "Modality's semantic map". Linguistic Typology, 2 (1): 79-124.

van Dijk, Teun. 2005. "War rhetoric of a little ally. Political implicatures and Aznar's legitimatization of the war in Iraq". Journal of Language and Politics, 4(1):1-10

van Dijk, Teun. 2006. "Discourse and manipulation". Discourse and Society, 17 (3): 359383.

van Dijk, Teun. 2011. "Discourse, knowledge, power and politics". In Critical Discourse Studies in Context and Cognition, ed. C. Hart (pp. 27-63). Amsterdam: John Benjamins.

White, Peter R.R. 2006. "Evaluative semantics and ideological positioning in journalistic discourse: A new framework for analysis". In Mediating Ideology in Text and Image, eds. I. Lassen, J. Strunck and T. Vestergaard (pp. 37-67). Amsterdam: John Benjamins.

\section{APPENDIX}

(i) BUSH: 22 texts; 27,917 words

http://georgewbush-whitehouse.archives.gov/

1. Statement by the President in His Address to the Nation, 11 September 2001

2. Address to a Joint Session of Congress and the American People, 20 September 2001

3. President Discusses War on Terrorism, Address to the Nation, 8 November 2001

4. President's Remarks to the Nation, 11 September 2002

5. President's Remarks at the United Nations General Assembly, 12 September 2002

6. President Discusses Growing Danger posed by Saddam Hussein's Regime, Radio Address by the President to the Nation, 14 September 2002

7. President: Iraqi Regime Danger to America is "Grave and Growing", Radio Address by the President to the Nation, 5 October 2002

8. President Bush Outlines Iraqi Threat, Cincinnati Museum Center, 7 October 2002

9. President Signs Iraq Resolution, 16 October 2002

10. President Pleased with U.N. Vote, Remarks by the President on the United Nations Security Council Resolution, 8 November 2002

11. President Bush: "World Can Rise to This Moment", Statement by the President, 6 February 2003

12. President's Radio Address, 1 March 2003

13. War on Terror, President's Radio Address, 8 March 2003

14. President Discusses Iraq in Radio Address, President's Radio Address, 15 March 2003

15. Statement of the Atlantic Summit: A Vision for Iraq and the Iraqi People,16 March 2003

16. President Says Saddam Hussein Must Leave Iraq Within 48 Hours, The Cross Hall, 17 March 2003

17. President Bush Addresses the Nation, The Oval Office, 19 March 2003

18. President Discusses Beginning of Operation Iraqi Freedom, President's Radio Address, 22 March 2003 
19. Operation Iraqi Freedom, President's Radio Address, 5 April 2003

20. Operation Iraqi Freedom, President's Radio Address, 12 April 2003

21. President Bush Addresses United Nations General Assembly, 23 September 2003

22. President Bush Addresses Nation on the Capture of Saddam Hussein, 14 December 2003

(ii) BLAIR: 17 texts; 27,988 words

http://webarchive.nationalarchives.gov.uk/

http://www.publications.parliament.uk/

1. September 11 attacks: Prime Minister's statement [11/9/2001]

2. PM's first statement to Parliament following the September 11 attacks [14/9/2001]

3. The PM's second statement to Parliament following the 11th September attacks [4/10/2001]

4. Prime Minister's statement to the House of Commons [8/10/2001]

5. Prime Minister's statement to Parliament on the war on terror [14/11/2001]

6. Prime Minister's speech to TUC conference in Blackpool: 'Saddam Hussein is a threat that has to be dealt with', 10 September 2002.

7. Prime Minister's statement to Parliament following the publication of the Iraq dossier: Prime Minister's Iraq statement to Parliament [24/9/2002]

8. PM statement on Iraq following UN Security Council resolution, 8 November 2002

9. PM's speech at the Lord Mayor's Banquet, 11 November 2002

10. Statement to Parliament following summit with President Bush [3/2/2003]

11. PM statement on Iraq [25/02/03]

12. PM statement following the Azores Summit, 16 March 2003

13. PM statement opening Iraq debate in Parliament [18/03/2003]

14. Prime Minister's Address to the Nation, 20 March 2003

15. PM statement: A strategy for peace in Iraq [14/04/2003]

16. PM statement at Downing Street on Saddam Hussein, 14 December 2003 